\title{
Reconstructing the Understanding of the Symbolic Meaning Behind the Architecture of Javanese Traditional House
}

\author{
Riandy Tarigan ${ }^{1, *}$, Antariksa ${ }^{2}$, Purnama Salura ${ }^{2}$ \\ ${ }^{1}$ Faculty of Engineering, Parahyangan Catholic University, Bandung, Indonesia \\ ${ }^{2}$ Faculty of Engineering, Brawijaya University, Malang, Indonesia \\ Received October 12, 2021; Revised December 28, 2021; Accepted January 16, 2022
}

\section{Cite This Paper in the following Citation Styles}

(a): [1] Riandy Tarigan, Antariksa, Purnama Salura, "Reconstructing the Understanding of the Symbolic Meaning Behind the Architecture of Javanese Traditional House," Civil Engineering and Architecture, Vol. 10, No. 1, pp. 305-322, 2022. DOI: 10.13189/cea.2022.100126.

(b): Riandy Tarigan, Antariksa, Purnama Salura (2022). Reconstructing the Understanding of the Symbolic Meaning Behind the Architecture of Javanese Traditional House. Civil Engineering and Architecture, 10(1), 305-322. DOI: 10.13189/cea.2022.100126.

Copyright $\odot 2022$ by authors, all rights reserved. Authors agree that this article remains permanently open access under the terms of the Creative Commons Attribution License 4.0 International License

\begin{abstract}
The architecture of traditional Javanese houses is full of symbolic meaning because they function as embodiments of the vertical (sacred), internal (private) and horizontal (social) relationships that are expressed in the activities, places, spaces and shapes as well as the meaning behind them. The current understanding of traditional architecture focuses on mere physical formation. The architecture of traditional Javanese houses is currently experiencing development both in terms of activities carried out in them as well as their physical shapes. These changes are caused by the added non-household activities, a shift of views on the part of the house owners and residents which results in the development of symbolic meaning. Understanding of the symbolic meaning behind the architecture of traditional Javanese houses - which separately examines the five aspects above - requires a deconstruction so that one may gain a thorough grasp of new understanding. The methods used are: (1) subjective observation on the activities and furniture arrangements in every room, the placements for the new activities and rooms for movement based on compositional principles. (2) Juxtaposing the structures of symbolical meaning between cosmological architecture of traditional houses with the current architecture of Javanese traditional homes to learn the development of symbolical meaning. (3) Conducting in-depth interviews to learn symbolical meanings according to the residents' views. These interviews are also
\end{abstract}

done to clarify the subjective research done by the researcher. The objective of this research is to obtain a research method that is able to express a deep, holistic understanding of symbolical meaning. The significance of this research is to pose as a stakeholder in formulating policies in relation to the continuity and enrichment of the architecture of traditional houses.

Keywords Reconstruction, Symbolical Meaning, Architecture, Traditional Javanese Houses, Theoretical and Methodological Understanding

\section{Introduction}

Humans are symbolical creatures (animal symbolicum) that are able to create, use, understand and grasp symbols in order to adapt to their environment [1]. Therefore, humans have existed in the environment as homo significance [2] [3]. To adapt, humans not only accept symbols, they also produce them through communication that is manifested in their culture. According to Cassirer, culture is the entirety of human ideas and works that must be familiarized with through learning alongside the entirety of these works, such as: language, art, and technology [4]. Through language, humans are inseparable from the omens 
of actualizing and communicating themselves with the objects around them, including the homes they live in. One of the products of human culture is residence or a place to live. Residence culture is a long cultural history which development spans over the course of human history. Residence is the function that lies the closest to the development of human culture. Therefore, a symbol that has been physically manifested would become an integral part of a residence, especially when it comes to the traditional homes of various tribes. One of them is that of the Javanese culture. The architecture of traditional Javanese homes is a manifestation one of the symbolical thing Javanese cultures, which consists of: centralism, dualism [6][7] dan cosmology [6][8]. The three aspects show that traditional Javanese homes are full of symbolical meanings as well as pragmatic ones.

To the Javanese, a house does not only function as means of shelter and procreation (private-internal aspect), and to socialize (public-horizontal aspect). A traditional Javanese house is a place that connects man as (microcosm) with The Creator (macrocosm), referred to as verticalism [8]. Therefore, its arrangement of space and shape is the embodiment of the three aspects (internal, vertical and horizontal).

The development of the architecture of traditional Javanese homes (from this point on abbreviated to ATJH) affects their symbolic meaning. This development consists of: the growing family size, change of ownership, abandonment by previous owner(s) and replacement with someone else, additional non-residential activities (industrial, lodging, opening a shop/stall, other forms of trade), and home renovations. The development of the $\mathrm{ATJH}$, especially for commerce and industrial purposes, changes the activities in a dwelling with all its structural additions, shifts, and reductions of activities in the traditional space. The change or addition of a new activity in a traditional space affects its symbolic meaning; making it no longer suit the condition of an authentic ATJH's symbolic meaning.

The current of understanding of the ATJH is divided into 2 (two) polar opposites. In the first pole, the ATJH is only understood based on the physical aspects of its spaces and forms. The ATJH is broken down based on the anatomy of its building's forms and its spatial arrangement. In the second pole, the ATJH is understood based on Javanese myth-related symbolisms. Both poles of understanding make for an absolute and static definition of the ATJH, even though in the ATJH, there is a dynamic shift that is based on the activities and perspectives of the residents who utilize these traditional spaces.

In the development of the understanding of the symbolic meaning of the ATJH, there are 2 phenomena: first, the activities and place of activities that change, add or erase the previous activities from being the main part in influencing the symbolic meaning - they are never deeply understood. This condition results in the ATJH to only be understood statically over time. The ATJH is confined by the suspension of time which means that the architecture of these traditional homes becomes strait-laced and unable to adapt to the present and future developments of Javanese culture. Ergo, the architecture of traditional Javanese homes cannot serve as the basis for contributing to Javanese housing concepts. In the future, the architecture of traditional homes will be left behind by the Javanese, because the ATJH is deemed incapable of adjusting to change of perspectives and needs of the current and future Javanese societies.

In the second phenomenon, the ATJHs are situated in areas that are dynamically in development, which are cities with heterogenous cultures, such as Kudus, Surakarta, Yogyakarta, and others. This opens up the possibility for a dynamic development of meaning, in relevance to the development of cultures and societies.

In planning for activities, spaces, and forms, the Javanese have their own way of creating harmony - which is suspected to differ from their culture in the past. According to Geertz [5], the current society has become a functional one, unlike the previous society which was still mythical in nature.

Based on the 2 aforementioned phenomena, understanding of symbolic meaning cannot be done with structuralist paradigm alone. Structuralism is qualitative research with a pattern of the symbolic meaning of the ATJH, about the symbolic meaning of ATJH in a cosmological manner as a reading tool. This is because the symbolic meaning at play has gone through: first, a symbolic meaning that occurs through the dynamics and placements of activities in a traditional space, prompting a new meaning to emerge. Second, the heterogenous nature of the urban society affects the coinage of this new meaning. This phenomenon requires a new explanation in understanding a symbolic meaning that not only covers the aspects of activities, spaces, and forms separately, but also as a unified interrelationship.

Disparity occurs between two sides; on the one hand, a house is part of human existence that is anything but lifeless. A house is something that is alive and constantly evolving. On the other hand, there is that desire an architect of a traditional Javanese home may have to try to retain the original meaning - especially the symbolic meaning this type of architecture contains in relation to the local wisdom. This disparity lies in the understanding of the symbolic meaning, a fight so that the ATJH would not lose its authentic meaning during its development.

This research's question focuses on ways to understand the dynamics of the symbolic meaning of the architecture of traditional Javanese homes in the context of added non-residential activities. Meanwhile, the objective of this research is to develop an architectural research method in order to enrich architectural theory, especially in the field of symbolic meaning within the scope of traditional architecture. The aspect of understanding the dynamics of symbolic meaning is significant for the enrichment of design methods for practitioners who would like to 
advance home architecture that is based on the concept of symbolic meaning. The results of this discourse are useful for stakeholders to use as the basis for formulating policies in relation to the continuity and enrichment of traditional home architecture.

\section{Materials and Methods}

\subsection{The Phenomenon}

The discourse departs with the basis of ontology, which is the phenomena that befalls the ATJH - as explained in the Introduction chapter- it concerns understanding the phenomenon of the symbolic meaning of the ATJH as an emerging reality. The phenomena are necessary in obtaining the truth in a factual problem found experientially, so that the result would be useful. The phenomena explained in the introduction show that a symbolic meaning develops dynamically and contextually, making it a blur. The phenomena found in the observed field show that what the activities are and where they take place are essential aspects in the existing traditional spaces. The development of activities that may occur are (1) a new activity replaces the old one, therefore potentially bringing the old activity to extinction, (2) a new activity is added to the old activity, both may co-exist simultaneously, and (3) an old activity is moved to another place. The development seen in every traditional space shows that the placements and forms of a traditional space have not been significantly changed. Judging from previous research, the study was not relational in terms of activities, forms and meanings that ended substantially with the death of traditional architecture. Traditional architecture is only observed based on its physical aspects, especially its roofing, so that in terms of building functionality, the shape of its roof is the only thing paid attention to, while the meaning at works in the building itself left unexplored.

\subsection{Phenomena Interpretation}

Phenomena Interpretation is a discourse conducted with theories and methods that serve as the basis for determining the application of field observations. Phenomena Interpretation aims to develop the framework of research methods in order to provide an image in understanding a symbolic meaning. To understand this, one must interweave theory, methodology and method into an interrelated unity in the research process so that the truth in understanding the dynamics of symbolic meaning during field observation can be accounted for.

The scope of ontologically-based understanding of a symbolic meaning consists of 5 (five) aspects that serve as the basis for field observation, which are: activity, place, space, form, and meaning. The scope of the interrelationship of the 5 (five) aspects can be seen in
Figure 1.

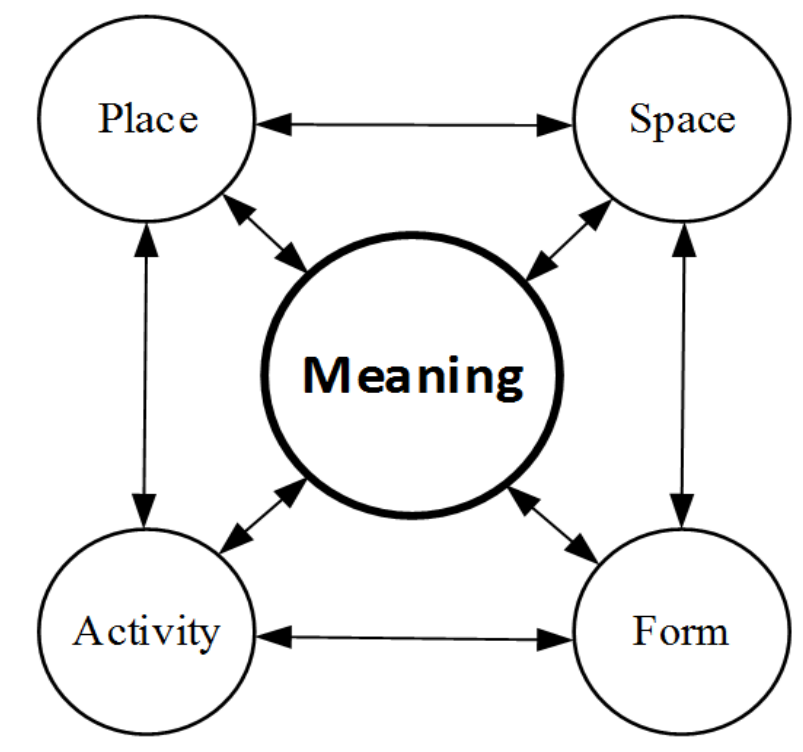

Figure 1. The scope of understanding of symbolic meaning

To understand the symbolic meaning of traditional homes, the following are conducted: first, conducting a study on the symbolic meaning of every activity that partakes in each space. Secondly, by studying the arrangement of activities along with their meaning. Third, by conducting a study on the relationship between symbolic meaning with the expressions of space and its forms. Fourth, by starting a discourse on the change in symbolic meaning between the previous ATJH with the current ATJH.

Based on the 3 bases, the theories used are as follows: (1) the theory of meaning by Salura [9], (2) the theory of the placement of activities and arrangements based on the theory of the principles of arrangement that contains the relationship between an activity and its placement within a traditional space by Salura [10], (3) the relation between symbolic meaning with space and form by Salura \& B. Fauzy [11], and (4) the theory of the development of meaning by Barthes [12] as the basis for denotative and connotative meaning. These three theories are elaborated to establish the basis for understanding the development of symbolic meaning.

The discourse on this theoretical elaboration is not value-free because the 4 theoretical discourses have been studied based on characteristics of the ATJH that are still cosmological. The results of this study will become the basis/way of understanding in the research of all case studies.

The existence of the phenomenon above provides a chance to understand the symbolic meaning of traditional homes. To discover the meaning of the ATJH requires a reconstruction of the theoretical basis and methods that will be carried out to answer the phenomenon of the dynamic development of symbolic meaning. 


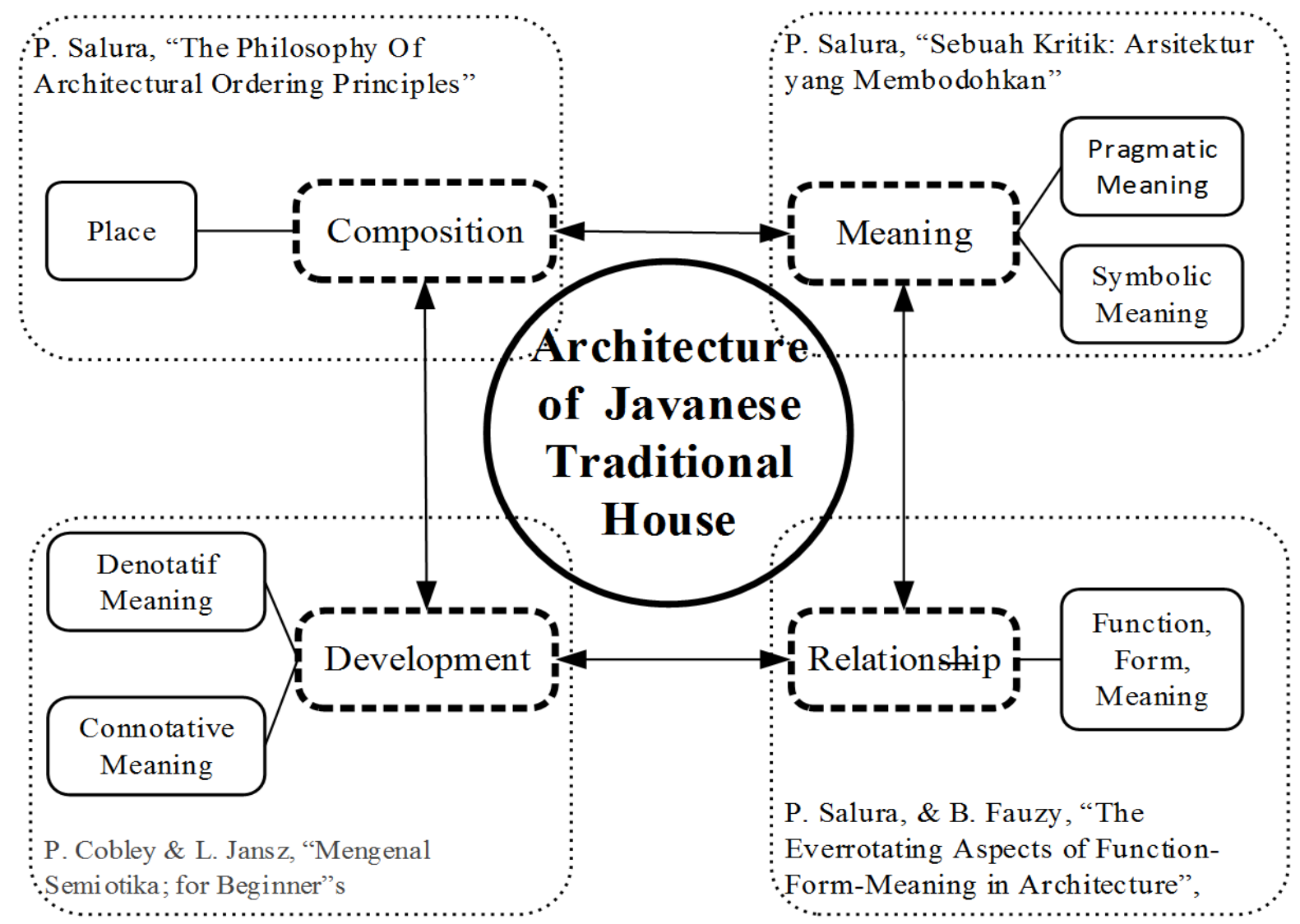

Figure 2. Theoretical Framework Diagram

\subsection{Material}

The research took place on the island of Java, more specifically Kelurahan ${ }^{1}$ Langgardalem of Kudus Regency in Central Java Province. The location can be seen in Figure 3 below.

\section{PETA NEGARA KESATUAN REPUBLIK INDONESIA}

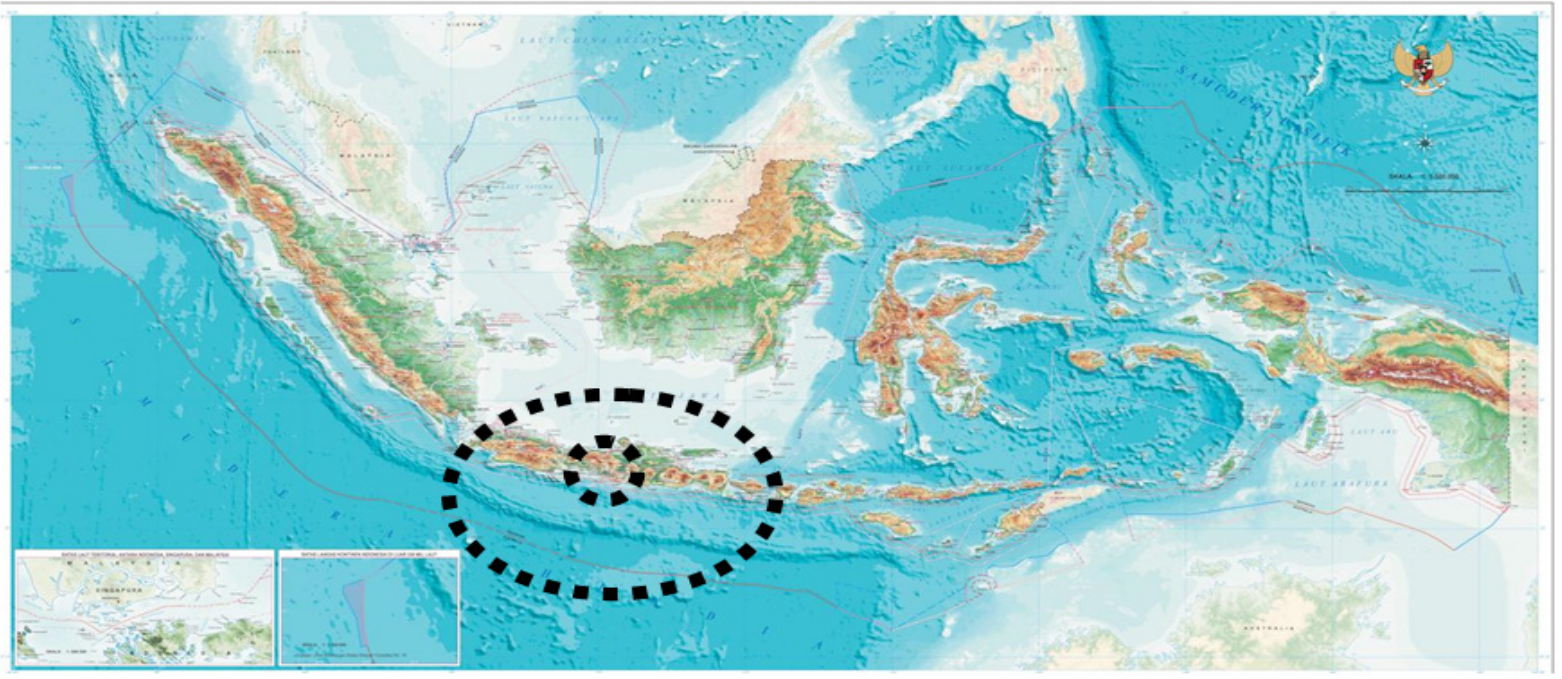

Source: https://indonesia.go.id/peta-indonesia/22, 24 December 2021

Figure 3. Map of Indonesia, Java Island and the location of Kudus District

1 Kelurahan or subdistrict is the fourth-level subdivision below a district, regency/city, and province. There are a number of names and types for villages in Indonesia, with desa being the most frequently used for regencies and kelurahan for cities. 
Here is a map showcasing the district, city, and kelurahan of Langgardalem, as seen in Figure 4 below.

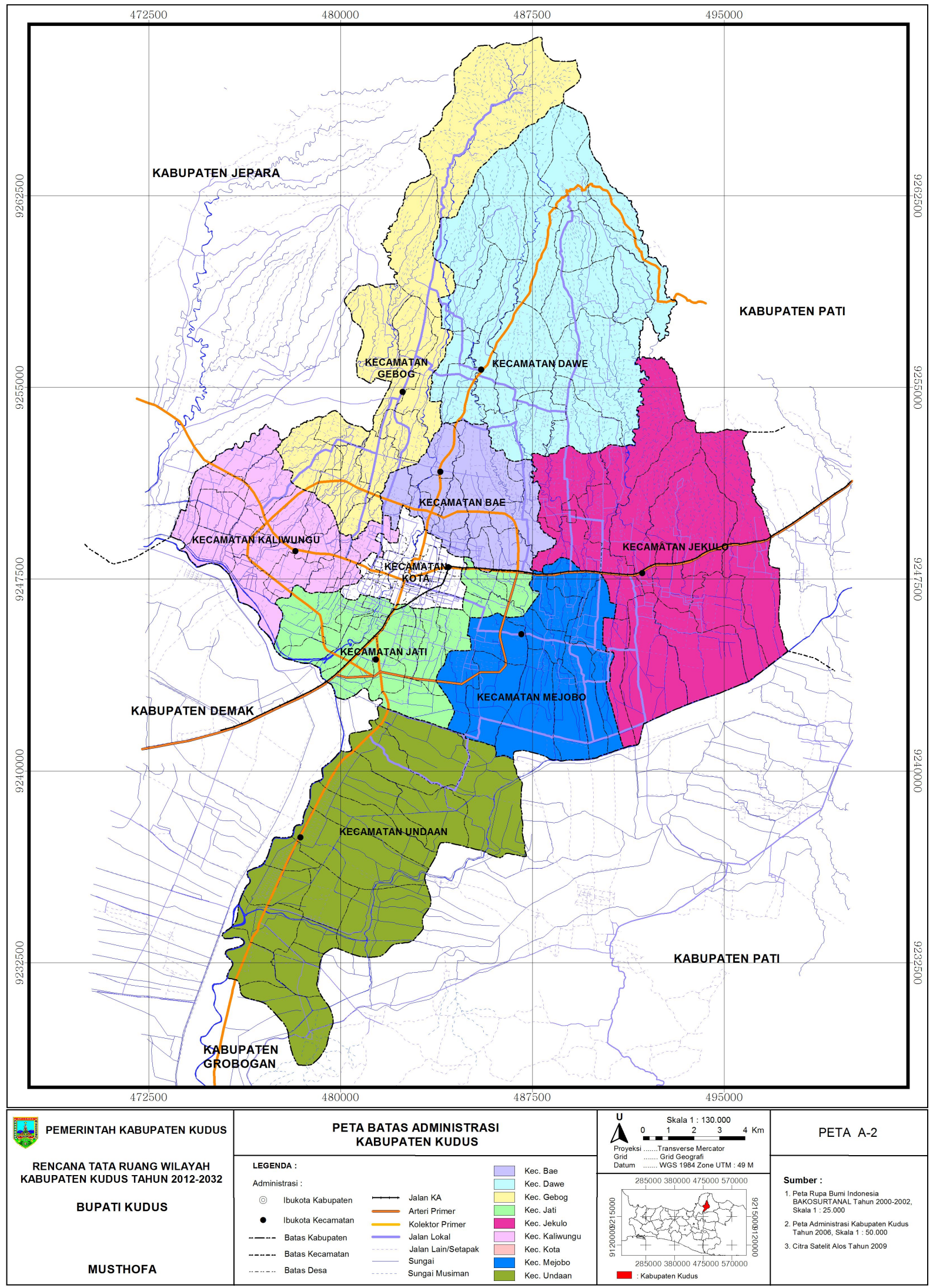

Source: https://polreskudus.com/profil/geografi/, 24 December 2021

Figure 4. Kudus Regency, District City and Kelurahan of Langgar dalem 


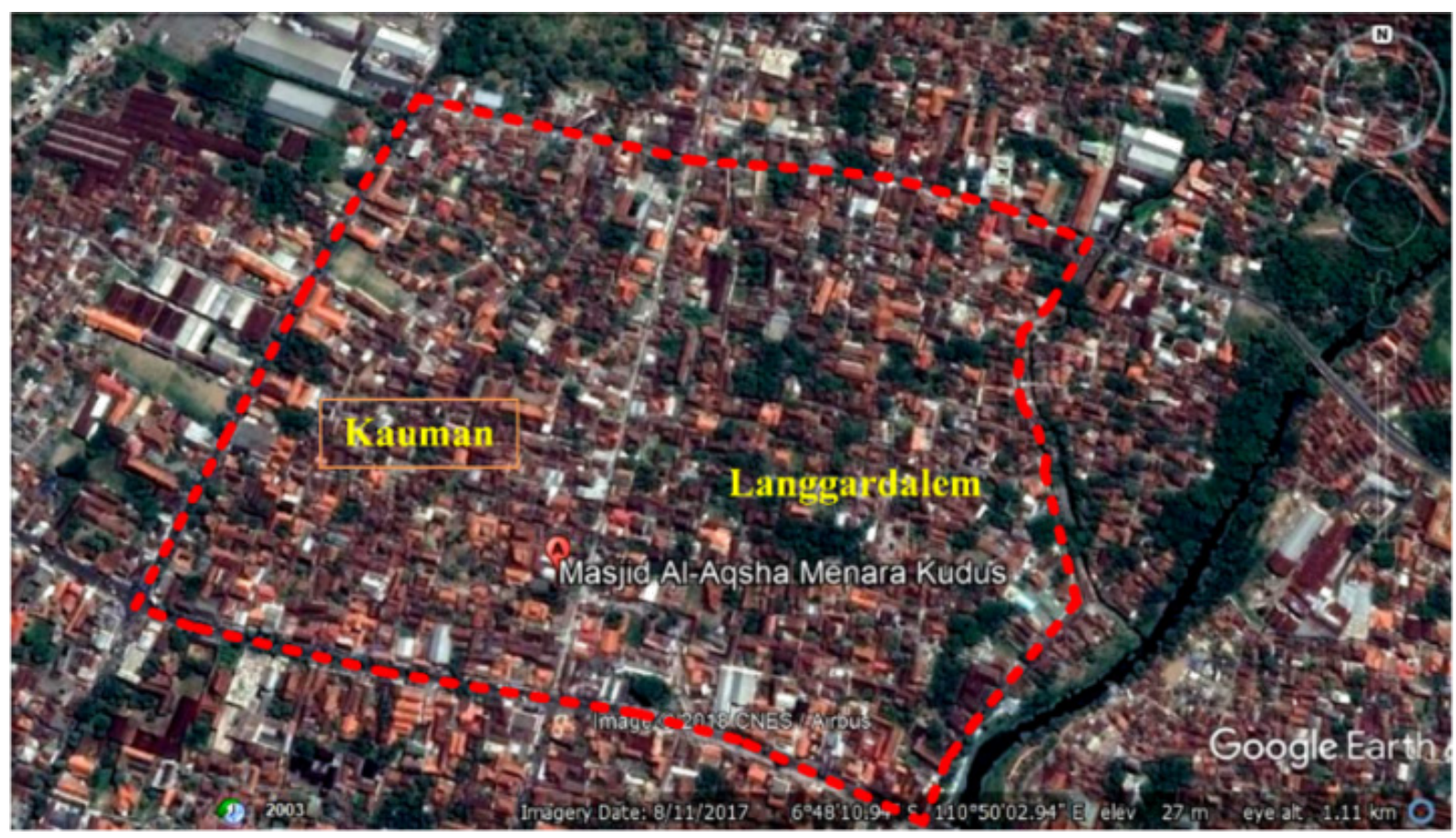

Source: Google Earth, taken, 2018

Figure 5. The location of Kelurahan Langgardalem which serves as this research's object of study

The location of Kelurahan Langgardalem can be seen in Figure 5.

Kelurahan Langgardalem is a traditional residential area that came about during the early development of the area. The residential area is heavily populated and is situated in the heart of the city of Kudus. These traditional residential houses still boast the classic structure of a traditional Javanese house to this day. The chosen cases for this study are 3 (three) different houses. In these houses, industrial functions have been added, which are: garment (clothes) and snacks production.

The condition of the case study houses consists of traditional houses that generally contain spaces referred to as a). Gedhongan which consists of: senthong kiwo, senthong tengah, senthong tengen and jogan; b) Jogosatru, c) pawon. The structures of space mentioned above can be seen in Figure 6 below.
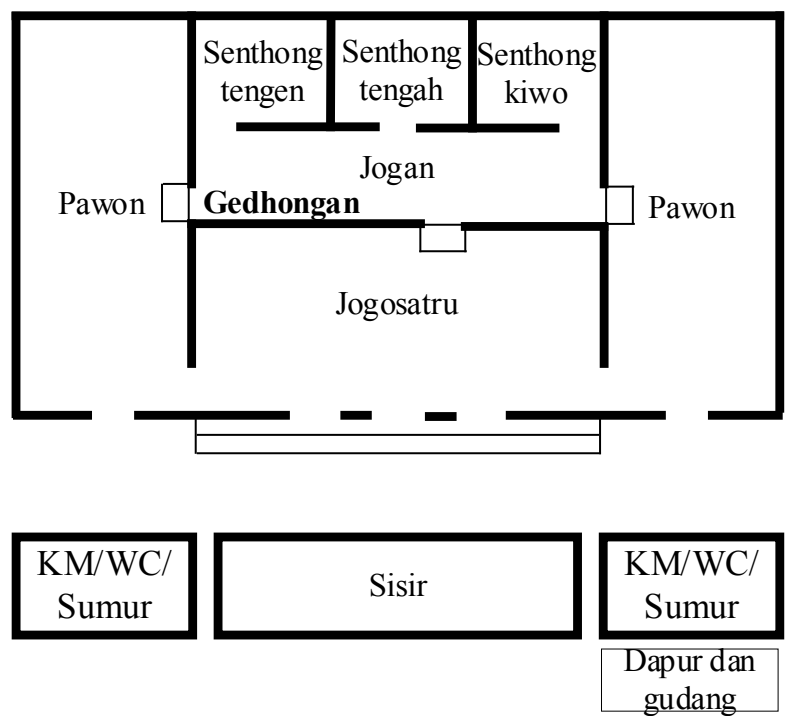

Figure 6. Type of space structure of traditional Javanese homes in Kudus 
The current conditions of the case studies are shown in figures 7, 8, and 9 below.

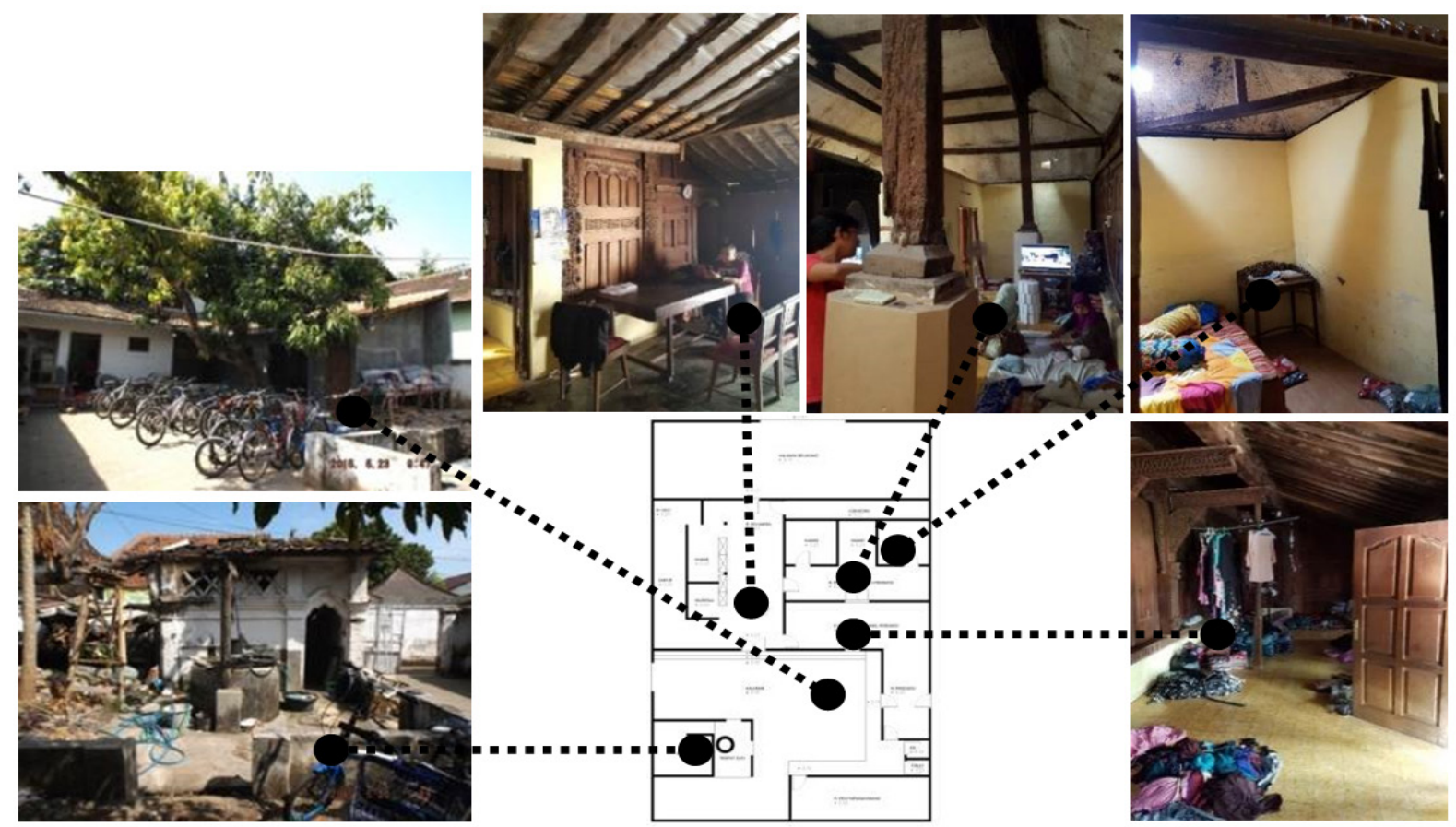

Figure 7. Cholid Isnawans house condition
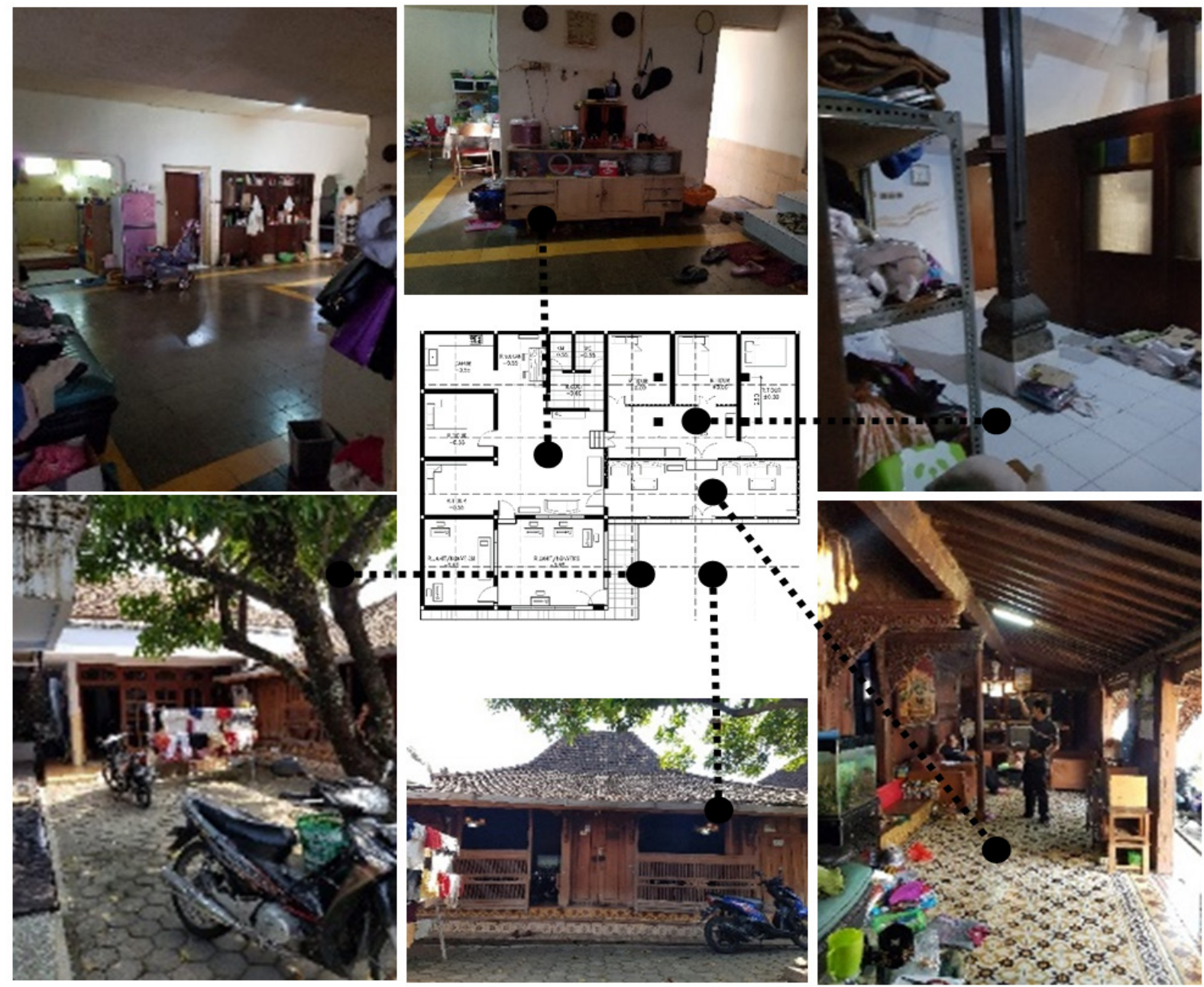

Figure 8. Yusdi Irvan's house condition 


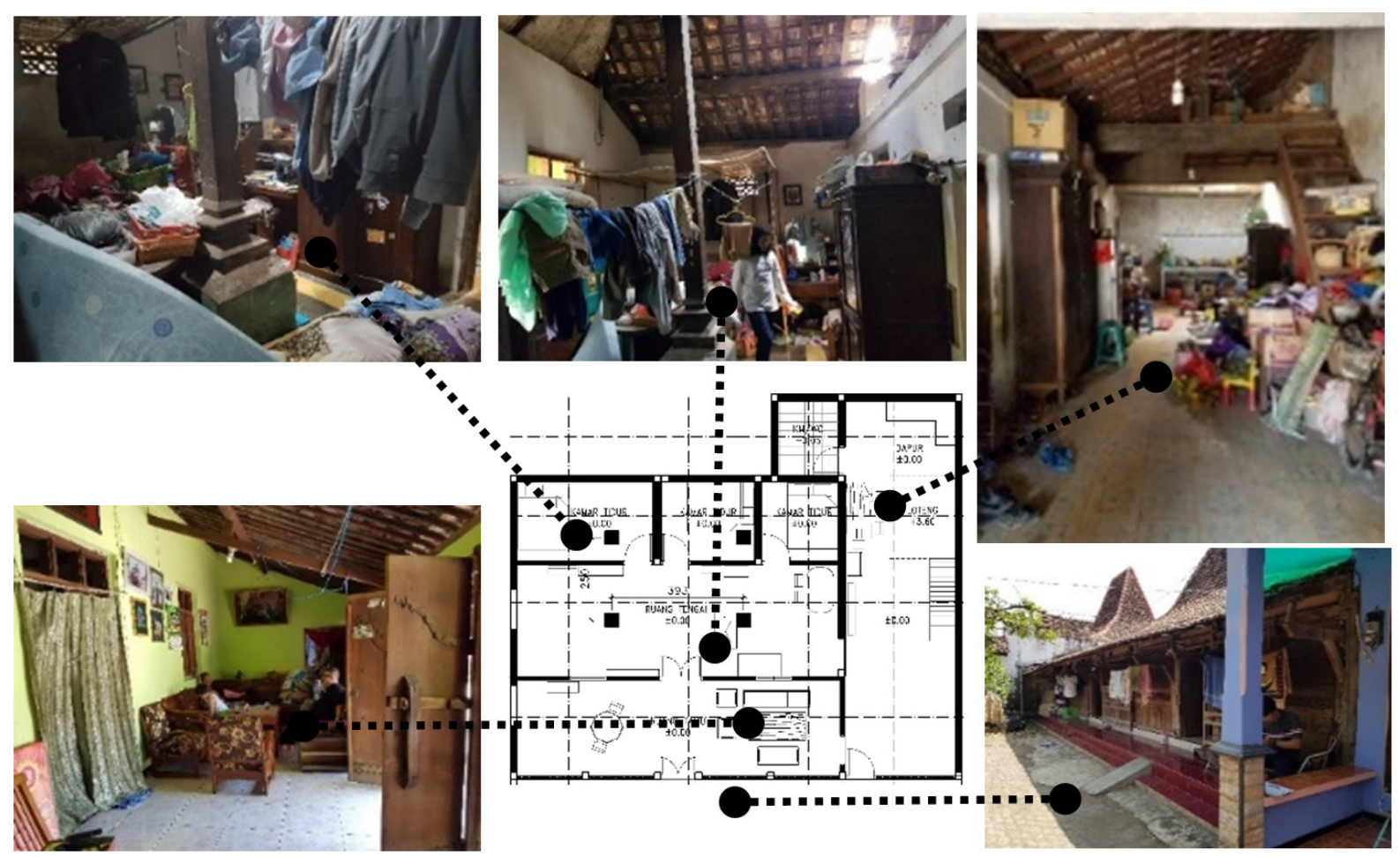

Figure 9. Mother Asriati's house condition

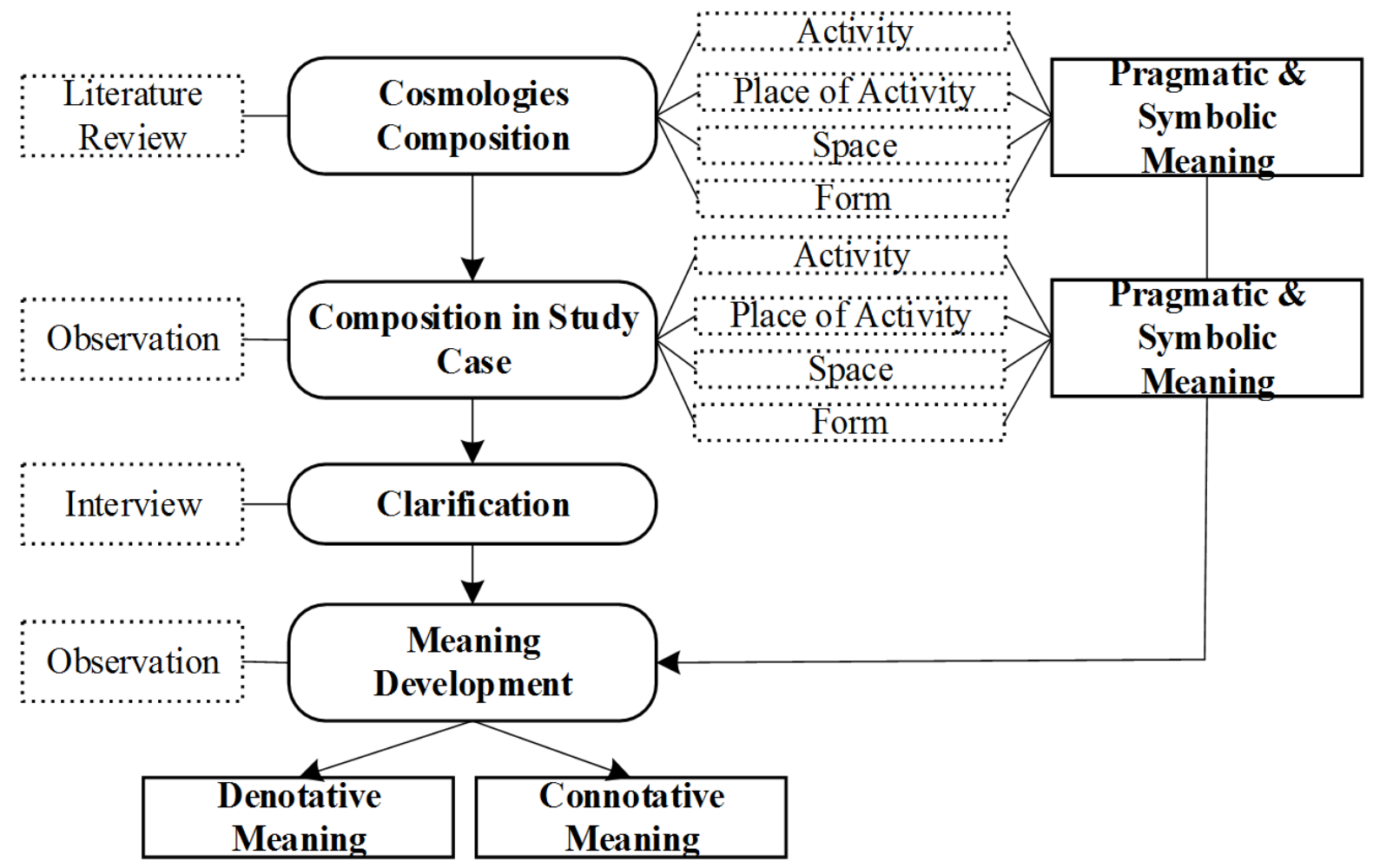

Figure 10. Method Framework of the Research 


\subsection{Research Method}

Based on the scope of understanding that has been laid out in the sub-chapter of the Introduction - the Phenomena Interpretation - there are 5 aspects in understanding symbolic meaning, namely: activity, place, space, form, and meaning. To obtain an understanding of symbolic meaning, research on these 5 aspects is not conducted separately, and is instead integrated rationally in order to obtain meaning based on the signs expressed. The methods conducted are based on two perspectives, which are the researcher's perspective (subjective) and the resident's perspective (objective) on symbolical meaning. The research method based on the researcher's perspective is done with the following ways: first, by theoretically understanding the symbolic meaning of the architecture of traditional Javanese homes through a literary discourse on every case study. This understanding is done to connect cosmological aspects with the arrangement of activity placements in every traditional space.

Secondly, by interpreting the symbolic meaning of the case studies of the architecture of traditional Javanese homes by observing the activities, placement of these activities and the spaces. An observation of these activities is conducted to determine whether an activity is a pragmatic or symbolical need. A pragmatic activity is an activity performed to fulfill daily, physical needs, while a symbolical activity is an activity that is sacred; a social expression or a ritual.

Third, by conducting in-depth interviews with the residents to find out their perspectives on the activity arrangements in these traditional spaces and the symbolic meaning behind these arrangements.

Fourth, by taking the symbolic meaning of the architecture of traditional Javanese homes that still relies on a cosmological basis, and comparing it with the architecture of traditional Javanese homes that have undergone changes due to added industrial activities. In this fourth step, Barthes' insight that develops denotative and connotative meaning is applied as the way to understand symbolic meaning.

The research method is laid out in the method framework in Figure 10.

\section{Result and Discussion}

In the lives of both humans and animals, order is a familiar concept [13]. Order has become the basis of arranging certain compositions; every human beingeither as an individual or as a group - takes part in establishing order. Animals, for example, assemble their nests under certain conditions, as oppose to doing so arbitrarily. Therefore, order is one of the essential aspects in understanding architecture - in this case, in understanding its symbolical meaning.

To achieve order, it is important to understand the aspects of space and activity placements that refer to the arrangement of traditional space. Order in Javanese culture departs more from a symbolic culture than a pragmatic one. A symbolic relation is shown in the placement of activities based on hierarchal and vertical relationships.

The concept of an activity's "place" is the most crucial stage in understanding symbolic meaning. The placement of an activity as designated by the resident has certain purposes and is motivated by certain perspectives of the inhabitants of a traditional space.

An understanding of symbolic meaning, when viewed based on its scope is divided into 4 (four) types, which are: the meaning of an activity, the meaning of a place, the meaning of a space, and the meaning of a form.

\subsection{The Concept of Residing}

The word "reside" or "inhabit" is a life process that takes place in a specific location where the resident implements the notion of settling not only with their physical body, but also with their very soul [14]. The concept of "residing" means to attract the environment outside oneself to become an environment inside one's life through arranged activities that provide meaning to the resident(s) [15]. To reside means having an arranged location to live in. The act of residing or inhabiting - both of which are common words used in daily lives - is a familiar concept. A residence is commonly understood as "a roof over one's head and several square meters to one's disposal" [16]. To reside is an act that is contingent on the resident(s) (possibly a family) as human subjects who perform the act of providing meaning to the artificial environment they create while also individually existing in the place and becoming part of the world they create at the same time [17].

A house is one of the products of a set of ideas, knowledge, beliefs/ideology, familial relationships, good and bad behavior, and an institutionalization made by people (the society) in the form of a residence. As a form of architectural culture, a home has the ability to manifest values and display the ways of living and the traditions of a society. Architecture, in this case of homes, is capable of showcasing the meaning contained in daily lives through cultural symbolization of all the cultural aspects found in a home [18].

The concept of residing, to the Javanese, is very closely tied to cosmological factors, because the culture calls for the entirety of human lives to be based off of their relationship with The Creator- which is poured into the vertical arrangement of their traditional spaces. A home is a small universe (micro-cosmos). A home (microcosmos) is the connector between humans with The Creator as the big universe (macrocosmos) [6]. Because a home serves as the center of it all, it becomes important. The fulcrum of a Javanese home is situated at the senthong tengah. The senthong tengah is a sacred ritual of leaving a space empty, 
as in no activity is performed in it even though there may be furniture laid out: a bed, with a complete set of pillows and bolsters. The senthong tengah is dedicated as a place to worship Dewi Sri. Dewi Sri is the goddess of rice who provides fertility for agriculture, specifically rice farming.

\subsection{Understanding Pragmatic and Symbolic Meaning}

Fundamentally, architecture possesses the ability to display how meaningful daily lives are through cultural symbolization that goes beyond immediate situations that are part of the continuation of culture and history. A Symbol is an abstraction of socio-cultural living that is implemented into the physical forms of its environment [19]. Oliver [20] defines a symbol as a conventional sign that originates from a habit.

Essentially, the discourse of meaning in the architecture of traditional Javanese homes is inseparable from the basis of Saussure's rationale, even though in the end, the understanding of meaning in architecture is dissimilar from Saussure's views in explaining the relationship between the signifier with the signified. The signified functions as an object, while the signifier is a concept provided to said object. This concept serves as the basis in providing meaning to an object. The relationship between the two is arbitrary; there is no causal relationship between the object and the meaning. The role of linguistics is inseparable from the context of architecture, so that the approach chosen for a structuralism-based architecture research is inseparable from the roles of language, systems of signs and meaning. All architecture objects have meaning according to Charles Jencks [21] and Geoffrey Broadbent [22].

The philosophy of meaning cannot be separated from the relationship of objects, signs and their meanings with an emphasis on the concept of the relationship between signs in which the signifier is a concept of thought and the signified is a form of meaning. Saussure argued that the structure of language can be seen as a sign system [23]. As a sign, the object must have a meaning. Without meaning, the architectural object is just a meaningless object. Architecture is the product of a sign system with its meaning.

There are several differences between sign and meaning between linguistics and architecture. Architecture is formed based on a construction which meaning has triple articulation instead of two as Saussurian signs, namely: shape, function, and technique [21]. The second difference - both of which are considered as systems of signs - is that language consists of a single unit, separated from arbitrariness, while architecture must consider the relationship and context of another object to create meaning. This other entity may take the form of an activity, place and space that may conclude various meanings, resulting a complexity of interpretations and making architectural code irreducible to separate units [24].

Salura and Fauzy [11] developed a relationship between the signified with the signifier based on architectural principles, namely the meaning produced by the relationship between function and form based on the phenomenological cycle from activities to meaning. The relationship between function and form is a process out of a structuralized activity and is limited by the field and structure that are composed to become meaning. This meaning is developed based on the cultural context that affects the function. Therefore, the search for meaning does not stop; instead, it is a dynamic process.

Providing meaning to a home is inseparable from signs. Meanwhile, a sign is related to an object. There are 2 kinds of objects, namely the physical and non-physical. A sign is an object that has been given meaning, in the sense that meaning and providing meaning are always related to the sign represented by a particular object. Because of that, the 3 aspects: object, sign and meaning are inseparable from one another. A sign which represents a particular object in architecture consists of an activity, activity place, space and form.

According to Eco [25], a sign in architecture is the main purpose to communicate function. This function consists of the system, an object and a space. In architecture, function serves as the fulcrum in the discourse of sign and meaning. Functions are classified not only based on their significance but also the types, in which practicality is put forth. According to Eco [25], there are two basic types of 'functions' in architecture, which are:

1. Primary and utilitarian functions in relation to usage. This function is referred to as the pragmatic function;

2. Secondary function in relation to symbolic values, cultural conventions and ideology. This function is also referred to as the symbolic function.

Eco argues that in communicating an architectural 'object,' the secondary function is more important compared to the primary, both spiritually and socially.

The pragmatic/primary meaning is a pragmatic meaning that is related to physiological needs. Physiological needs consist of the need for comfort, safety, security, health and ease. Functional meaning is based off of efficiency and effectivity aspects of a need. According to Istanto [26], Mangunwijaya explains that architecture consists of convenience and imagery (guna dan citra). These are related to needs that call for efficiency and effectivity. The need for comfort consists of: the body, the sight, the hearing, and the sense of smell. The need for safety and security consists of the need to be safe from disasters and accidents along with security from theft. The need for health consists of the need to be free of disease, poison, pollution and foul smells.

A symbolic meaning is a meaning formed with a purpose outside of a pragmatic/primary meaning, which consists of an imagery-expressive purpose by its user based on their psychological, socio-economic, cultural, existential aspects that are manifested into their activities, 
placements of place, space and form. According to Salura [27], a symbolic meaning is not related to its effective function and is instead "excessive," in the sense that the expression of a symbolic meaning exceeds its pragmatic meaning. Symbolic meaning produces forms that exist outside the aspects of similarity and causality. The form of said meaning no longer refers to its likeness and basis of its function, it instead has a new interpretation that grows out of a particular individual or group interests as a sigil/symbol.

As previously explained, the relationship between sign and meaning in architecture is not arbitrary nor it is value-free. There are two types of meaning: pragmatic and symbolic. The understanding of symbolic meaning consists of 2 properties: relational and contextual. Relational meaning is not only related to the forming elements of the signified that consist of an activity, place, space and form; it is instead influenced by the interrelationship between the 4 (four) signified properties themselves. A contextual meaning is intended to be dependent on each resident, as in residents that are given rights and authority (power) in managing the family.

\subsection{Relational Meaning}

\subsubsection{Understanding the Meaning of an Activity}

Activities that take place in the ATJH are expressions of human culture which consist of forms, ways and social lives that manifest out of ideas, knowledge, beliefs, familial relationships, good behavior and its institutionalization [28], which in them contain pragmatic and symbolic activities. Commonly-known pragmatic activities such as private activities (to rest, to study, et cetera), public activities (receiving guests, chatting with friends, neighbors, et cetera), acts of service (to shower, do laundry, go to the bathroom, to cook, keep items, et cetera). Symbolic activities consist of: worship, ritualistic celebrations (from prenatal to death), laying out offerings (sesajen), meditation, et cetera) [5][29]. All of these activities are carried out at home and are reserved to particular spots at home and supported by the deliberate placements and arrangements of furniture in relevance to the symbolic activities performed in them.

In current development, a house does not only function as a place to reside in. Traditional homes currently function as means for commercial trade and services, even industries. The addition of non-residential activities impacts the existence of traditional spaces in the sense that they call for replacements, additions, reductions, and removal. This affects the pragmatic and symbolic meaning, as well as the relationship of signs (space and form) with the symbolic meaning as well as the development of symbolic meaning itself.

Thus, the concept of activities is the basis in any study of place, space, form, and meaning in the architecture of traditional Javanese homes. It has been explained that activities in Javanese culture are not only based on pragmatic needs, but also symbolic needs. The understanding of the symbolic meaning is shown in the properties of activities. The observation of symbolic meaning is based on the approaches of property and composition [10]. The observation of properties is based on the properties of activities and spaces. In the principle of composition from the theory of "Ordering Principles", there are two aspects that are studied, namely aspects of order and movement (circulation). The observation of composition consists of order, or the placement of an object relative to other objects. This placement determines the front-back, top-bottom, center-periphery, and inside-outside positions. Circulation includes linear, centered, radial, grid and clustered circulations. These observations are made on the objects in a given space, such as furniture, utensils, or equipment; the movements of people, and the placements of activities in traditional spaces.

The understanding is built upon the aspect of dualism, which is the basis for the division of activities [6]. Dualism is a structuralist approach that operates within pairs of polar opposites (binary opposition). The understanding of space in Javanese society develops from simple figures and forms into complex ones. The dualism of space according to the Javanese view, such as right-left, low-high, front-back, top-down, north-south, profane-sacred, and others, is expressions of spatial attitudes and orientations [8].

The properties used are not physical ones such as floors, walls, or roofs, but activities. Property uses aspects of activities that have the characteristics of space that are based on dualism, such as: private-public, individual-communal/social, formal-non-formal, quiet-crowded, static-dynamic, and inward-outward. Activities are also assessed based on the aspects of gender (male-female) and leadership (leader-non-leader). In traditional Javanese home architecture, the division between activities and space is based on the gender-based division of areas where activities take place. Likewise, leadership in Javanese family culture is based on patriarchy, i.e. the power to control the family is held by men (the male parent) who are always in formal contact with society, while women play the domestic role of taking care of the household. Gender and leadership factors affect the symbolic meaning of placement.

In understanding the symbolic meaning of activities, activities are understood as signs. Signs are divided into two: the activity itself and its movement. Activities, supporting equipment (furniture, tools, etc.), and movements are influenced by their objectives, so that they can be realized based on functional (pragmatic) or non-functional (symbolic) needs. Spiritual activities and ceremonies commemorating pregnancy, birth, 8 months after birth, circumcision, marriage, and death are activities that have a more dominant symbolic meaning compared to the pragmatic meaning. 
Objects or equipment that has a symbolic meaning are those used with a specific purpose to fulfill non-functional (symbolic) needs. For example, a bed is placed in a certain room, but it is not used for sleeping. Ceremonial activities such as those have different forms and sequences of activities than those of activities. The characteristics of these activities and movements become the basis for the structural system of place, space, and form, as well as the system of symbols.

\subsubsection{Understanding the Meaning of Place as the Embodiment of the Place of Activities}

In addition to cultural activities, the place where activities take place is also a form of cultural expression that influences the context of a specific meaning, because a place is a geographical area that is specifically formed, thereby giving rise to a specific culture formed within an architectural configuration that mediates between life and the inhabited world [30][31]. This is a part of the events, memories, habits, rituals, moods, nostalgia and experiences. It shows "intimacy" that forms a narrative or story between places and activities that are related to life, as an expression of the existence of an activity that is more important than the "space" [17][32][33][34]. Place is thus referred to as a 'topogenesis', that is, the "genetic and epistemological study of place" as a cultural system [35].

In that sense, place always has an aspect of a memory/recollection/remembrance of a particular event, such that place becomes an integral part of its genius loci, related to narratives that foster values that were previously unknown and create meaning in the present.

From the discussion above, place has a profound concept in the context of understanding meaning. In this case, the concept of place is of interest in research. The concept of "place" can be viewed from to aspects, namely "Sense of Place" and "ordering principles", to understand the placement of activities in a traditional spatial order. The understanding of "place" is related to the Sense of Place (hereinafter abbreviated as SoP). 'SoP' refers to "a sense related to psychology and emotions", perceptions, and attitudes, which are expressed in the relationship of human beings with their physical environment [36][37][38]. Thus, the term 'SoP' includes objective and subjective aspects that are the actions of and reactions between human perception and the physical elements of architecture. Therefore, the 'interaction' between places and activities is the essence of the search for spatial characteristics.

In contrast to the "SoP" principle, according to the theory of Ordering Principles [10], an object is meaningful when it is connected to another object. Thus, objects have meaning when they are in a unity with other objects. The Ordering Principles theory explains that in composition there are 2 aspects, namely: property and composition. Properties are the objects, while composition is the existence of the objects relative to other objects.

Basically, every place of activity, space, and form has certain orders or rules with pragmatic and symbolic purposes. Every composition that is formed shows that each element is one part of the entire composition (a part-whole model). The positions of place, space, and form create their own compositions, which are each built upon the order of its elements [9]. The order of objects has certain patterns known as nodal points, routes, and boundaries [10]. The three patterns are always present in every order of existing spaces. The patterns are a characteristic and a nature of activities that impact space and form. This order is based on the nature of circulation, and it affects the meaning of a place, as well as its value. The patterns in the placement of activities in certain locations have an important meaning if they are contrary to the pattern of circulation. Thus, these places are closely related to their activities and movements.

In light of the discussion above, the concept of place based on the aspects of property and composition becomes significant in creating the concept of place in the realm of traditional architecture in relation to symbolic meaning. Symbolic meaning in the realm of traditional architecture is strongly influenced by activities, the place of activities, the division of places in traditional spaces, the expressions of field elements, structures, and ornaments. The concept of place in the case of understanding symbolic meaning places more emphasis on the relations and interactions between architectural objects/elements rather than understanding place as an interaction between location and events as described in the "SoP" principle in determining meaning. This is because events have become a unity between activities and placements that are manifested in space and form.

Based on "SoP", meaning views a place as an individual matter that is related to human emotions/spiritual/feelings about the place, but has not been associated with other objects and places. In this case, place is considered as something that stands alone. On the other hand, in the traditional spatial structure, the placement of an activity, both sacred and profane, is shown in how the positions of the activity and the space are in an interconnected unit (contextual in the "body" of traditional Javanese home architecture). Therefore, theoretically, the theory of Ordering Principles [10], especially the aspect of composition, is the basis for determining the place to find the relationship between symbolic meaning and the basis for placement in traditional Javanese spaces. This theory can be a method to understand the meaning that occurs in traditional Javanese home architecture today, which has experienced developments and changes in activities in traditional spaces.

The understanding of symbolic meaning in the architecture of traditional Javanese homes today has undergone developments and changes due to the inclusion of non-residential activities. The developments of these activities affect the order of activities in traditional spaces that already have certain symbolic meanings. By juxtaposing the symbolic meaning of a place in traditional 
Javanese home architecture that was based on cosmology with the current traditional Javanese home architecture, it is possible to arrive at the meaning of the place where current activities take place.

Place is a sign aspect that can show a certain symbolic meaning through its placement in a building. Places that have symbolic meaning are shown in the meaning of activities, supporting equipment, and movements. Activities that have symbolic meanings are placed in certain locations not based on physiological needs, such as the distance between places of activities which is determined not based on the closeness of the relationship between activities. For example: the seat of the king has a symbolic meaning in its placement at a certain place with a certain height.

\subsubsection{Understanding the Meaning of Space as a Container of the Place of Activities}

Space is the embodiment of the container of the place of activities. Space is expressed through the dimensions of space in three dimensions. The embodiment of space is a volumetric dimension resulting from the need for activities. Space has a symbolic meaning if the volumetric dimension given is not only based on the pragmatic needs of the activity, but also its symbolic needs.

An understanding of the meaning of space is evident in the understanding of space as a sign. Signs in space are the basis for meaning. Interpretable signs in space consist of the dimensions, hierarchy, and nature of the space. Dimensions can indicate whether the space has a symbolic or pragmatic meaning. Dimensions that exceed the physical needs of activities have a tendency to have certain symbolic meanings, whether from the spiritual-sacred, economic, status/position, or social and cultural aspects. The sign of the meaning of space is shown on a spatial scale. The hierarchy of space is shown in the dimensions (scale) of space, the position of space relative to other spaces, differences in form with other forms of space, and distance from and accessibility to other spaces.

Understanding space is done by understanding the nature of space. In accordance with the characteristics of traditional space, which are based on cosmology, the nature of space is understood as dark-light, empty-filled, and open-closed. Meanwhile, in terms of the composition of space, it is almost the same as place, namely top-down, front-back, center-periphery, outer edge-inner edge, inside-outside [10]. The nature of dark, empty and inward spaces tend to have symbolic meaning, compared to spaces with an opposite nature. Likewise, central placement gives an important meaning to activities that are positioned as the center of a residential home.

The meaning of space in the case study develops or changes as a result of the addition of non-residential activities. The developments of activities affect the meaning of space based on the development of the symbolic meaning of activities and places of activities. The establishment of the symbolic meaning of space is not only shown in the meaning of activities and the place, but also the signs shown in a space through its dimensions, hierarchy, and nature. Based on field observation, the dimensions, place, and form of the space have not changed significantly. This creates a contradiction with new activities that replace previous activities. For example: senthong tengah is currently turned into a space that functions as a place for resting, storing products, studying, and others. Previously, senthong tengah was an empty space used as a place of worship and salat (Islamic prayer) which had a symbolic meaning.

\subsubsection{Understanding the Meaning of Form}

Form is the most tangible physical embodiment in the creation of meaning. Physical forms consist of: plane elements (roof planes, wall planes, floor planes and openings), structures and ornaments. Form is a part of the sign or object for the expression of meaning that is applied to the activity, the place of activity, and the space. For example: the opening (window/door) on a wall is an expression of the meaning of the activities or circulation in it, either a pragmatic or symbolic meaning.

Based on field observations, there are different understandings of meaning. For the symbolic meaning in form, there are relational and non-relational meanings. Relational symbolic meaning is a symbolic meaning based on the meaning of an activity and the place of activity. Non-relational symbolic meaning is a meaning that stands alone and is unrelated to any activity or place of activity, but rather is a symbolic meaning that is presented based on the interests of the dwellers, for example: ornaments/carvings on tiles, paintings on walls, carvings on roof tiles, stairs and so on.

Such non-relational symbolic meaning is not directly related to architectural elements. Thus, in understanding meaning, particularly symbolic meaning, it is necessary to have an in-depth knowledge about whether the symbol is related to the meaning of the activity, place of activity, architectural space, or form, as a symbol of the local community's perspective.

\subsection{Contextual Symbolic Meaning Based on Architectural Elements and the Residents' Views}

\subsubsection{Contextual Meaning in Architectural Elements}

It has been explained in the understanding of pragmatic and symbolic meanings that meaning has two aspects, namely relational and contextual meanings. Contextual meaning is the formation of meaning through sign holistic elements that are integrated between activities, places, spaces, and forms. Based on field observations, understanding meaning cannot be done with only the approach of relational meaning. This happens because activities, places, spaces, and forms influence each other and are related to each other in the formation of meaning.

The formation of meaning from activities consists of 
four alternatives, namely: a) pragmatic activity-symbolic meaning; b) pragmatic activity-pragmatic meaning; c) symbolic activity-symbolic meaning; d) symbolic activity-pragmatic meaning. The four conditions are affected by their place and circulation, which is explained as follows:

\section{(a) Pragmatic activity-symbolic meaning}

In traditional Javanese home architecture, pragmatic activities can have symbolic meanings based on their placement.

For the first example, parents' sleeping habits have a symbolic meaning because they are "placed" in gedhongan, or in the center, which symbolizes how parents are respected in a Javanese family. The activity in Jogan is a pragmatic activity, but the activity is placed in a dark and empty room; therefore, it has a certain symbolic meaning.

For the second example, the activity of receiving guests (pragmatic activities) in the architecture of a traditional Javanese home in Kudus has a symbolic meaning. The symbolic meaning is shown in the carved wall elements that are different from the relatively simple walls in the gedhongan and pawon. The placement in front shows that the activity has a pragmatic meaning.

For the third example, the sanitation system in traditional Javanese architecture in Kudus is a pragmatic activity placed in front and separated from the main building. Although the location of the sanitation system is in front, where it is crowded and full, it has a symbolic meaning based on its separate location from the main building. However, a separate placement is not the basis for determining meaning, because the placement of sisir, or a separate building for commercial activities such as operating a shop, does not make it have a symbolic meaning.

The three cases above show that the creation of symbolic meaning can be done through placements and expressions of form.

\section{(b) Pragmatic activity-pragmatic meaning}

Pragmatic activities which are interpreted to have pragmatic meanings occur in service activities, such as cooking, storage of goods, sanitation activities, and communal (family) and social (society) activities. This meaning is based on the place of activity, which is placed on the periphery of the building, both inside and outside.

\section{(c) Symbolic activity-symbolic meaning}

Symbolic activities are sacred and/or ritual in nature, such as worship, prayer, meditation, and ritual ceremonies. In traditional Javanese home architecture, symbolic activities are placed at the center and become the axis of the home. Worship activities are the essence of the meaning of Javanese people's spiritual life, which evinces the relationship between human beings and the Creator. Humans are in the microcosm, and the Creator is in the macrocosm, which is connected by a central area in the home called senthong tengah. The symbolic meaning of senthong tengah, other than being indicated by the place, is also indicated by the nature of the activity and space. The nature of the activity is "silent", "closed" and "inward". The nature of space is "empty" and "dark". These are the characteristics of gedhongan.

\section{(d) Symbolic activity-pragmatic meaning}

Symbolic activities that express a pragmatic meaning occur in the development of symbolic activities that no longer use senthong tengah. In most case, senthong tengah has been turned into a room for resting, especially for the elderly, or unused and remains empty.

Symbolic activities that have a pragmatic meaning are a result of the transfer of the place of worship to pawon.

From the explanation above, it can be expounded that, to understand of symbolic meaning, it is not possible to use a theoretical explanation that uses idioms or the basis of cosmological Javanese traditional home architecture as a criterion to understand the architecture of traditional Javanese homes that experience the addition of non-residential activities. In the understanding of the symbolic meaning of traditional Javanese home architecture of today, there has been an increase in non-residential activities, which are not only based on view, whether from the perspective of activity, place, space and form, but the points of view become a unity that influence each other. The meaning of the view of the activity can be studied based on the placement, the nature of the space, and the expression of its form.

For example, in the case of traditional Javanese home architecture today, resting is carried out in senthong tengah. It is known that senthong tengah is a space that has symbolic activities and symbolic meanings. Because the activity carried out there has been changed into resting, it becomes a place for a pragmatic activity. Judging from its placement at the center, senthong tengah has a symbolic place meaning. Judging from the nature of the space that is bright, occupied, and dynamic, the meaning of the space is pragmatic.

Contradictory changes in meaning from the aspects of activity, place, space, and form provide a way for an approach to reconstructing a comprehensive and substantial understanding of the symbolic meaning. The symbolic meaning is not black-and-white, but there is a gradation of meaning in the traditional space which is no longer compatible with the cosmological symbolic meaning of Javanese traditional home architecture. Furthermore, the reconstruction of symbolic meaning can provide a more substantial and conceptual understanding of symbolic meaning.

\subsubsection{Symbolic meaning based on the residents' views}

The study of relational and contextual symbolic meaning has not been able to fully address the construction of symbolic meaning. This is because the meanings between 
the aforementioned four aspects are contradictory in sub chapter 3.4.1, either based on the current architecture of traditional Javanese homes, or based on the juxtaposition between cosmological Javanese traditional home architecture with the current architecture of traditional Javanese homes.

Thus, an understanding of the symbolic meaning has to be developed through approaches from the researchers and the residents. This is done as an effort to find the ultimate truth through the research. The importance of research based on the residents' views is due to the rapid, dynamic, and heterogeneous developments of symbolic meaning that occurs in traditional settlements in urban areas, which are different from the developments in traditional settlements in rural areas or remote tribes, which are relatively slow, static and homogeneous.

Changes in the symbolic meaning in settlements in urban areas develop based on the views of individual residents. This is strongly influenced by the characteristic of the urban culture, which is individualistic in contrast to the more communal rural areas. This trait of individuality is influential in determining the symbolic meaning.

The heterogeneity of urban communities also affects the diversity of residents' views, which are not only influenced by non-residential activities. The development of knowledge as well as socio-cultural and technological influences must be taken into consideration in understanding the symbolic meaning of traditional Javanese home architecture. The heterogeneity of the society makes the structure of symbolic meanings diverse.

The approach to understand the construction of symbolic meaning by the residents was carried out using the Spradler ethnographic method [39]. The purpose of using the ethnographic method in doing research on the residents was to gain a comprehensive understanding of the symbolic meaning. This was done because the current residents have their own perspectives on symbolic meanings that are different than those of the people in the past.

Research on residents was carried out to measure the validity of previous research which focused on the researchers, so that the results of these studies have a high level of objectivity and can be accounted for.

\subsection{The Development of Symbolic Values}

The relation between sign and meaning according to Barthes generally refers to Saussure's principle of relation, which is static [40]. The difference is that, according to Barthes, meaning develops in accordance with the development of changes that occur in the sign. Meaning can be a sign back and produce new meanings in accordance with the development of the sign. Barthes distinguishes between denotative meaning and connotative meaning, the latter of which is open and non-absolute. Denotative meaning is the meaning that is still directly related to the first sign, or is permanent. Connotative meaning is the meaning signifying the first meaning which has become a sign. Barthes states that the reproduction of meaning is dynamic and evolving, in the sense that the meaning that defines a sign is not only permanent (absolute, stable, static and fixed), but non-permanent (non-absolute, unstable, dynamic and not fixed).

For more clarity, Barthes' diagram of the reproduction of meaning [41][42] is shown in Figure 11.

\begin{tabular}{|c|c|}
\hline 1. Signifier & 2. Signified \\
\cline { 1 - 1 } 3. Denotative Sign & \\
\hline 4. Connotative Signifier & 5. Connotative Signified \\
\hline \multicolumn{2}{|c|}{ 6. Connotative Sign } \\
\hline
\end{tabular}

Figure 11. A map of how signs work according to Barthes

This can happen because of the influence of the development of activities within ATJH, such that residents rearrange the new significance of the space and form of ATJH. The relationship between the sign and the meaning is reciprocal, or correlative between the previous sign and the connotative meaning of the same object. The relationship between signs with new connotative meanings can be seen in Figure 12. 


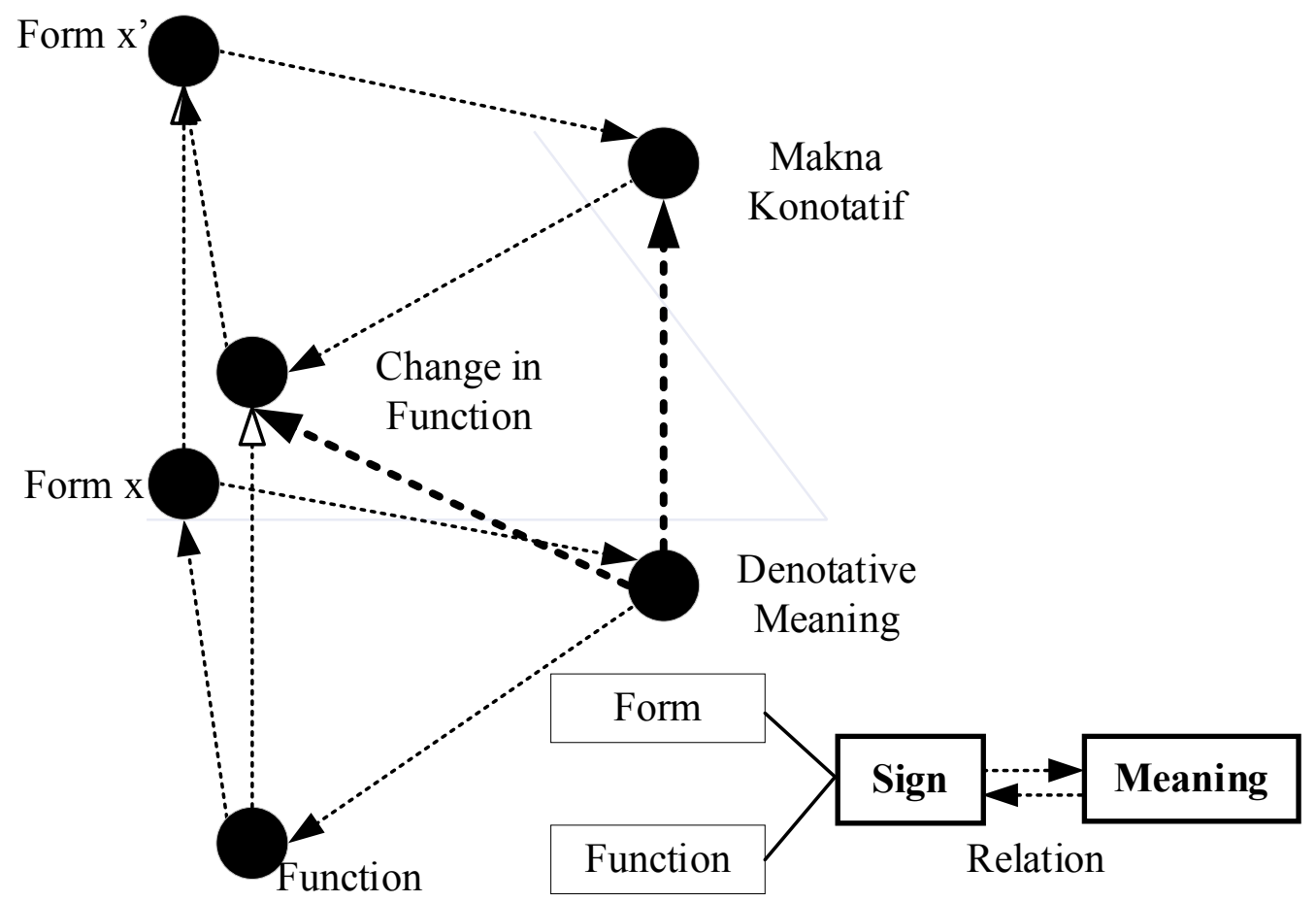

Figure 12. Barthes' relation between Function, Form, and Meaning, from Salura

Symbolic meaning has five alternatives, namely:

(a) Symbolic meaning experiences no change (unchanged) and its location is unchanged;

(b) Symbolic meaning experiences no change (unchanged), but its location is changed;

(c) Symbolic meaning experiences a change and becomes different from its previous meaning, and its location is unchanged;

(d) Symbolic meaning experiences a change into pragmatic meaning;

(e) There is an addition in symbolic meaning; location is unchanged.

\section{Conclusions}

The study of meaning in the architecture of traditional Javanese homes is carried out through not only one aspect, but rather four, namely activities, places of activity, space, and form, in a comprehensive manner. These four aspects are used because the symbolic meaning of traditional Javanese home architecture today is unclear when compared to the cosmological Javanese traditional home architecture.

The reconstruction of symbolic meaning is carried out in 4 (four) stages, which include, among others: first, conducting a study of the cosmological Javanese traditional home architecture as a criterion for reading the current architecture of traditional Javanese homes; second, conducting a study of the symbolic meaning in the case study based on relational and contextual symbolic meaning.

In the examination of meaning, place is a more important and strategic aspect than space, because space and form in traditional Javanese home architecture today remain relatively unchanged and tend to be sustained. Place is a chronological framework of the occupants in positioning their activities within the composition of traditional spaces.

Composition is an important tool to understand the order made by the residents in constructing symbolic meanings in traditional spaces.

The reconstruction of the understanding of meaning is due to the fact that the development of meaning is not static and absolute, but rather is non-permanent and unstable, in the sense that meaning is always evolving. This happens because the development of meaning that occurs in urban areas is fast and dynamic. Therefore, the understanding and creation of meaning are necessary.

The understanding of meaning is not only viewed from various aspects, such as the cosmological aspect of Javanese culture, but also requires an architectural approach through composition and a clarification of the occupants' (objective) interpretation of architectural signs.

\section{Statement}

This paper is the gist of the doctoral dissertation research conducted at the Doctoral Program in Architecture at Parahyangan Catholic University, Bandung, Indonesia (2016-2021) entitled: The Persistence of the Symbolic 
Meaning of Traditional Javanese Home Architecture in the Context of Adding Small Industrial Activities (Case study: homes in Kauman and Langgardalem, Kudus and Laweyan, Surakarta)).

I express my gratitude to Prof Antariksa, M.Eng., PhD., M. Arch., who is the main dissertation supervisor and Prof. Dr. Purnama Salura, MT., MT, who is the dissertation supervisor who has guided the writing of this dissertation.

I also convey my respect for Soegijapranata Catholic University and the Sandjojo Foundation for supporting my doctoral studies from beginning to end.

\section{REFERENCES}

[1] E. Cassirer, "Petunjuk kepada Kodrat Manusia: Simbol," in Manusia dan Kebudayaan: Sebuah Esei tentang Manusia", (translation by A. A. Nugroho), Jakarta:: PT. Gramedia, 1990, pp. 4-36.

[2] P. Salura, S. Clarissa, R. C. Lake, "Reflecting the Spirit of Modern-Indonesia Through Architecture: The Icono-Symbolical Meanings of Jengki Architectural Style Case Studies: Bandung Polytechnic of Health Building and Bumi Sangkuriang Meeting Hall in Bandung, West Jawa, Indonesia," Journal of Design and Built Environment, vol. 20, no. 2, pp. 13-26, 2020a, https://doi.org/10.22452/jdbe. vol20no2.2,

[3] P. Salura; S. Clarrisa; R.C. Lake, "The Application of Sundanese Vernacular Concept to The Design of Modern Building - Case Study: Aula Barat (West Hall) of Bandung Institute of Technology, West Java, Indonesia," Journal of Design and Built Environment, vol. 20, no. 1, pp. 1-12, https://ejournal.um.edu.my/index.php/jdbe/article/view/23 $634 / 11589,2020 \mathrm{~b}$.

[4] E. Cassirer, "Manusia dan Kebudayaan," in Manusia dan Kebudayaan: Sebuah Esei tentang Manusia", (translation by A. A. Nugroho), Jakarta:: PT. Gramedia, 1990, pp. $95-335$

[5] C. Geertz, "Abangan Variant," in The Religion of Java," London: Collier-Macmillan Limited, 1960, pp. 11-120

[6] G. Tjahjono, "Cosmos, Center, and Duality in Javanese Architecture,' in Cosmos, Center and Duality in Javanese Architectural Tradition: The Symbolic Dimension of House Shapes in Kota Gede and Sorroundings," University Of California, Berkeley, 1988, pp. 211-237

[7] S.R. Ju, D.Y. Kim, dan R.B. Santosa, "Dualism in the Javanese House and Transformation With Focus on the Houses of Kotagede, Yogyakarta," Journal of Asian Architecture and Building Engineering, vol. 17, no. 1, pp. 71-78, 2018, DOI: 10.3130/jaabe.17.71

[8] R. Waterson, "Cosmology," in The Living House: An Anthropology of Architecture in South-East Asia," Oxford, New York: Oxford University Press, 1990, pp. 91-114.

[9] P. Salura, "Bagaimana Menciptakan Ketidakharmonisan Hubungan Fungsi-Bentuk-Makna dalam Perancangan Arsitektur," in Sebuah Kritik: Arsitektur yang Membodohkan," Jakarta: Gakushudo, 2015, pp. 65-105
[10] P. Salura, "The Philosophy Of Architectural Ordering Principles," International Journal of Engineering and Technology (UAE), vol. 7, no. 2.9, p. 52-55, 2018, DOI: 10.14419/ijet.v7i2.9.13346

[11] P. Salura, \& B. Fauzy, "The Everrotating Aspects of Function-Form-Meaning in Architecture," Internasional Journal of Basic and Applied Scientific Research,, vol. 2, no. 7, pp. 7086-7090, 2012, www.textroad.com, ISSN 2090-4304

[12] D. Rusmana, "Semiotika Roland Barthes: dari Struktural ke Post Struktural," in Filsafat Semiotika: Paradigma, Teori, dan Metode Interpretasi Tanda dari Semiotika Struktural hingga Dekonstruksi Praktis," Bandung: Penerbit Pustaka Setia, 2014, pp. 181-214

[13] N. Crowe, "Geometry and the Primacy of Dwelling," in Nature and the Idea of a Man-made World: an Investigation into the Evolutionary Roots of Form and Order in the Built Environment," Cambridge: The MIT Press, 1995, pp. 31-69

[14] C. Norberg-Schulz, "House," in The Concept of Dwelling, On the Way to Figurative Architecture, New York: Rizzoli International Publications, Inc, 1985, pp. 89-91.

[15] P. Korosec-Serfaty, "Experience and Use of the Dwelling," in Home Environments, New York and London, Plenum Press, 1985, pp. 65-86.

[16] C. Norberg-Schulz, "Dwelling in Consistence," in The Concept of Dwelling, On the Way to Figurative Architecture, New York: Rizzoli International Publications, Inc, 1985, pp. 11-30

[17] P. T. Karjalainen, "House, Home and the Place of Dwelling," Scandinavian Housing and Planning Research, vol. 10, no. 2, pp. 65-74, 1993, https://doi.org/10.1080/028157393087 30324

[18] C. Norberg-Schulz, "Symbolitation," in Intentions in Architecture," Oslo: Universitetsforlaget, 1968, pp. 53-82

[19] Rapoport, "Socio-cultural Factors," in House, Form and Culture," New Jersey: Prentice-Hall, 1969, pp. 46-82

[20] P. Oliver, "Introduction," in Shelter, Sign \& Symbol, London: Barrie \& Jenkins, 1975, pp. 8-21..

[21] C. Jencks, 'Semiology and Architecture,' in Meaning in Architecture, (C. Jencks \& G. Baird (eds.), London: Design Yearbook Limited, 1969, pp. 10-25

[22] G. Broadbent, “A Plain Man's Guide to the Theory of Signs in Architecture," in Theorizing a New Agenda for Architecture. An Anthology of Architectural Theory, 1965-1995, (K. Nesbitt, eds.), New York, Princeton Architectural Press, 1996, pp. 122-140.

[23] J. Niven, "Meaning In Architecture... Is The Traditional Semantic Model Adequate?," Architectural Theory Review, vol. 1, no. 1, pp. 130-134, 1996, DOI: $10.1080 / 13264829609478270$

[24] G. Dorfles, "Structuralism and Semiology in Architecture," in Meaning in Architecture, C. Jencks \& G. Baird (eds.), London: Design Yearbook Limited, 1969, pp. 39-49.

[25] U. Eco, "A Componential Analysis of the Architectural Sign /Column/," Semiotica, vol. 5, no. 2, pp. -, 1972, http:// doi.org/10.1515/semi.1972.5.2.97. 
[26] F. H. Istanto, "Arsitektur "Guna Dan Citra" Sang Romo Mangun, In Memoriam: Yusuf Bilyarta Mangunwijaya6 Mei 1929-10 Februari 1999," Jurnal Dimensi Teknik Arsitektur, Vol. 27, No. 2, 1999, pp. 40-47, http://puslit.petra.ac.id/journals/architecture/

[27] P. Salura, "Simbol dan Arsitektur," in Ber-arsitektur: Membuat, Menggunakan, mengalami, dan memahami Arsitektur, Bandung: Architecture \& Communication, 2001, pp. 65-72.

[28] E. Öncüoglu, "Conceptual Basis Of Meanings in the Space Utilization," in Cultural Meanings In The Traditional House and The Modern Apartment Flat," The Department of Interior Architecture and Environmental Design and The Institute Of Fine Arts of Bilkent University, Turkey, 1996, pp. 5-12.

[29] R. B. Santosa, "Memaknai Omah," in Omah: Membaca Makna Rumah Jawa," Yayasan Bentang Budaya, Yogyakarta, 2000, pp. 1-31

[30] S. Unwin, "Architecture as Identification of Place," in Analysing Architecture, London: Routledge, 1997, pp. $12-17$

[31] D. Cojanu, "Homo Localis. Interpreting Cultural Identity as Spirit of Place," Procedia: Social and Behavioral Sciences, vol. 149, no. -, pp. 212-216, 2014.

[32] Y. Özmetin, “"Place” and Architecture, Some Ways of Thought," in Genealogy of Place in Architecture: History, Current Interpretations and Insight," Graduate School of Natural and Applied Sciences, Middle East Technical University, 2008, pp. 45-62, http://etd.lib.metu.edu.tr/uplo ad/12610086/index.pdf

[33] P. Pellegrino, "Space, Time, Semiotics," in ELSA, Environment, Land, Society: Architectonics, vol. 2, no. I-II, Lausanne: International Council for the Architectural
Research (ICAR), 2010, pp. 10-24, http://www.icar-elsa.ch

[34] N.-I. Terzoglou, "Architecture as Meaningful Language: Space, Place and Narrativity," Linguistics and Literature Studies, vol. 6, no. 3, pp. 120-132, 2018, DOI: 10.13189/1ls.2018.060303.

[35] S. Shamai, S. Arnon, I. Schnell, "From home to community and settlement: Sense of Place in Different Scales," Studies on Home and Community Science, vol. 6, no. 3, p. 153-163, 2012, DOI: 10.1080/09737189.2012.11885381.

[36] Y.-F. Tuan, "Common Psychological Structure and Response," in Topophilia: A Study of Environmental Perception, Attitudes and Values," Morningside Edition, New York: Colombia University Press, 1974, pp. 13-29

[37] E. Relph, "The Essence of Place," in Place and Placelessness," London: Pion Limited, 1976, pp. 29-43

[38] Y.-F. Tuan, "Experienial Perspective," in Space and Place: The Perspective of Experience," Minnesota: University of Minnesota Press, 1977, pp. 8-18

[39] C. Norberg-Schulz, "Dwelling and Existence"" in Genius Loci: Towards a Phenomenology of Architecture," New York: Rizzoli, 1979, pp. 13-30

[40] J. P. Spradley, "Etnografi dan Kebudayaan," in Metode Etnografi, Yogyakarta: Tiara Wacana, 1997, pp. 3-24

[41] W. Nöth, "Barthes's Text Semiotics," in Handbook of Semiotics," Bloomington and Indianapolis: Indiana University Press, 1990, pp. 310-313

[42] P. Cobley \& L. Jansz, "Introducing Semiotics," Cambridge: Totem Books, 1997, pp. 43-52

[43] R. Barthes, "Denotasi dan Konotasi," in Elemen-elemen Semiologi, (translation by K. Nazaruddin), Yogyakarta: Jalasutra, 1994, pp. 91-97 